\title{
DOCUMENTATION OF INPUT AND OUTPUT FILES FOR A GROUND-WATER-FLOW MODEL OF THE MILFORD-SOUHEGAN GLACIAL-DRIFT AQUIFER, MILFORD, NEW HAMPSHIRE
}

By Thomas J. Mack and Philip T. Harte

Supplement to Water-Resources Investigations Report 91-4177

U.S. GEOLOGICAL SURVEY

Open-File Report 92-60

Prepared in cooperation with the

U.S. ENVIRONMENTAL PROTECTION AGENCY, REGION I

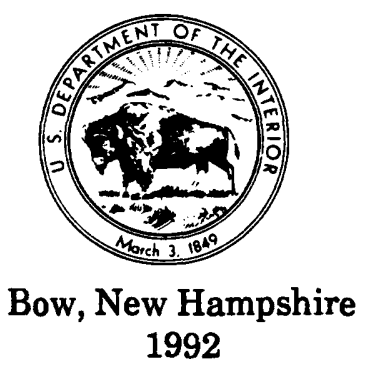


U.S. DEPARTMENT OF THE INTERIOR

MANUEL LUJAN, JR, Secretary

U.S. GEOLOGICAL SURVEY

Dallas L. Peck, Director

For additional information write to:

District Chief, NH-VT Office

U.S. Geological Survey

525 Clinton St.

Bow, New Hampshire 03304
Copies of this report can be purchased from:

U.S. Geological Survey

Books and Open-File Reports Section

Box 25425

Federal Center

Denver, CO 80225 


\section{CONTENTS}

\section{Page}

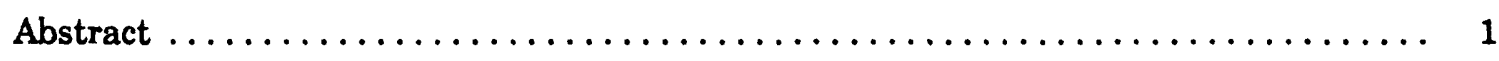

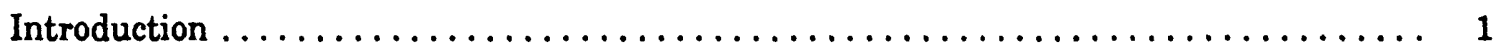

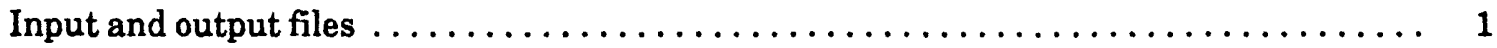

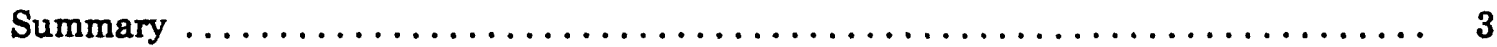

References cited $\ldots \ldots \ldots \ldots \ldots \ldots \ldots \ldots \ldots \ldots \ldots \ldots \ldots \ldots \ldots \ldots \ldots \ldots \ldots \ldots$

\section{TABLES}

Page

Table 1. Model-input files, size, and descriptions $\ldots \ldots \ldots \ldots \ldots \ldots \ldots \ldots \ldots$

2. Model-output files, size, and descriptions $\ldots \ldots \ldots \ldots \ldots \ldots \ldots \ldots \ldots$ 


\title{
Documentation of Input and Output Files for a Ground-Water-Flow Model of the Milford-Souhegan Glacial-Drift Aquifer, Milford, New Hampshire
}

\author{
By Thomas J. Mack and Philip T. Harte
}

\begin{abstract}
Documentation of input and output files for the ground-water-flow model of the Milford-Souhegan glacial-drift aquifer, Milford, New Hampshire, is presented in this report. Model input and output are given for two different sets of withdrawals in the model. The data files are contained on three $51 / 4$-inch diskettes that require 2.9 megabytes of storage on a personal computer and are presented in format according to the American International Standard Code for Information Interchange.
\end{abstract}

\section{INTRODUCTION}

A five-layer digital ground-water-flow model was developed for a study of contributing areas to two former supply wells in the Milford-Souhegan glacialdrift aquifer, Milford, New Hampshire, in cooperation with the U.S. Environmental Protection Agency. The model was developed for use with the ground-waterflow computational algorithm MODFLOW (McDonald and Harbaugh, 1988) and the post-processor, pathline algorithm MODPATH (Pollock, 1989). Results of the Milford-Souhegan aquifer study are reported by Harte and Mack (in press).

Although the report by Harte and Mack (in press) summarized model development, complete and detailed documentation of model-input and output files had not been previously published. The purpose of this report, which supplements the report by Harte and Mack (in press), is to provide complete documentation of all model-input data sets and two examples of model output in a form that facilitates use of the model.

\section{INPUT AND OUTPUT FILES}

The original input-data files and MODFLOW output for the Milford- Souhegan model were created on a Prime ${ }^{1}$ computer, with the use of Geographic Information Systems software, and then transferred to an IBM-compatible personal computer (operating under MS-DOS version 3.31). Files on the diskettes are identical to the original Prime computer files and

1 The use of brand, firm, or trade names in this report is for identification purposes only and does not imply endorsement by the U.S. Geological Survey. 
are presented according to the American Standard Code for Information Interchange (ASCII).

Although the model program runs on a variety of computers, the user may have to reorganize the input data if the specific computer and compiler used are not compatible with the data sets as presented. There is no way to anticipate the type of system that may be used to run the Milford-Souhegan model or which compiler will be used for the model program, which is written in Fortran 77.

Input-file names are listed in table 1 and outputfile names are listed in table 2. Each table lists the file name, the size in bytes, and a brief description. All files are in formats required for input by, or produced by output from, MODFLOW (McDonald and Harbaugh, 1988) or MODPATH (Pollock, 1989). Two sets of ground-water withdrawals (pumping conditions) were simulated: model-estimated pre-1983 conditions and current (1988) conditions (Harte and Mack, in press). Files specific to both simulated hydrologic conditions are provided. For example, two well-package input data sets are listed: WELL83.DAT for the 1983 withdrawal conditions and WELL88.DAT for the 1988 withdrawal conditions. There are 5 model layers; each layer requires a starting-head array that was used for both conditions. They are listed as HEAD1.DAT through HEAD5.DAT

Files for the Milford-Souhegan model are on three high-density, double-sided, soft-sectored diskettes requiring a total storage capacity of 2.9 megabytes. The input files listed in table 1 are contained on diskettes 1 and 2 and the output files listed in table 2 are contained on diskette 3 .

Model-layer data sets are designated by number 1 for the shallowest or uppermost layer and number 5 for the deepest or bottom layer. To simulate groundwater flow by use of the MODFLOW (McDonald and Harbaugh, 1988, Chapter 5) different data sets are required, which depend on whether the layer is simulated as unconfined, confined, or convertible between unconfined and confined. For the Milford-Souhegan ground-water-flow model, layer 1 is simulated as unconfined, and layer 2 is simulated as confined and convertible to unconfined if layer 1 becomes dewatered. Layers 3,4 , and 5 are simulated as confined layers. To simulate ground-water flow with MODFLOW, hydraulic conductivities and layer elevations are required for layers 1 and 2 . Layers 3,4 , and 5 require tran smissivity arrays and not elevations. Top and bottom elevations of layers 3,4 , and 5 are included on the diskettes because they are required for MOD-
PATH (Pollock, 1989) flow-path simulations. The only non-MODFLOW format data set required by MODPATH is a "main" data set (similar to the MODFLOW BCF data set) listed as PATH.DAT in table 1.

The two output files listed in table 2 (provided on diskette 3) can be used to confirm that input files, model setup, and program operation are correct after the model is ported to another computer. The MODFLOW program is required to generate cell-by-cell fluxes and head values as output files in binary format. Binary files are generally not portable and therefore, are not provided in this report. Cell-by-cell fluxes and head values, in binary format, are required input to the MODPATH program along with other files listed in table 1. These files can also be used as input files for programs to calculate head contours (Harbaugh, 1990a) and water budgets by model zone (Harbaugh, 1990b).

\section{Table 1.--Model-input files, size, and descriptions}

[IBOUND is a variable showing status of model cell; VCONT is a variable expressing both vertical hydraulic conductivity and vertical grid spacing]

\begin{tabular}{|c|c|c|}
\hline File name & $\begin{array}{c}\text { Size } \\
\text { (bytes) }\end{array}$ & Description \\
\hline BAS.DAT & 908 & Basic package data \\
\hline BCF.DAT & 1,907 & $\begin{array}{l}\text { Block-centered-flow } \\
\text { package data }\end{array}$ \\
\hline BOT1.DAT & 57,625 & $\begin{array}{l}\text { Bottom altitude, layer } 1 \\
\text { (shallowest layer) }\end{array}$ \\
\hline BOT2.DAT & 57,608 & Bottom altitude, layer 2 \\
\hline BOT3.DAT & 57,608 & Bottom altitude, layer 3 \\
\hline BOT4.DAT & 57,608 & Bottom altitude, layer 4 \\
\hline BOT5.DAT & 57,608 & $\begin{array}{l}\text { Bottom altitude, layer } 5 \\
\text { (deepest layer) }\end{array}$ \\
\hline HEAD1.DAT & 57,152 & Starting heads, layer 1 \\
\hline HEAD2.DAT & 57,152 & Starting heads, layer 2 \\
\hline HEAD3.DAT & 57,152 & Starting heads, layer 3 \\
\hline HEAD4.DAT & 57,152 & Starting heads, layer 4 \\
\hline HEAD5.DAT & 57,152 & Starting heads, layer 5 \\
\hline HYCON1.DAT & 103,968 & $\begin{array}{l}\text { Hydraulic conductivity, } \\
\text { layer } 1\end{array}$ \\
\hline HYCON2.DAT & 103,968 & $\begin{array}{l}\text { Hydraulic conductivity, } \\
\text { Taver ? }\end{array}$ \\
\hline
\end{tabular}


Table 1.--Model-input files, size, and descriptions-Continued

\begin{tabular}{|c|c|c|}
\hline File name & $\begin{array}{c}\text { Size } \\
\text { (bytes) }\end{array}$ & Description \\
\hline IBOUND1.DAT & 28,120 & Boundary, layer 1 \\
\hline IBOUND2.DAT & 28,120 & Boundary, layer 2 \\
\hline IBOUND3.DAT & 28,120 & Boundary, layer 3 \\
\hline IBOUND4.DAT & 28,120 & Boundary, layer 4 \\
\hline IBOUND5.DAT & 28,120 & Boundary, layer 5 \\
\hline OUTCON.DAT & 526 & Output control data \\
\hline PATH.DAT & 2,144 & $\begin{array}{c}\text { MODPATH main } \\
\text { package data }\end{array}$ \\
\hline RECHARGE.DAT & 113,840 & Recharge data \\
\hline RIVER.DAT & 44,890 & River and stream data \\
\hline SIP.DAT & 74 & $\begin{array}{l}\text { Strongly implicit } \\
\text { procedure data }\end{array}$ \\
\hline TOP2.DAT & 57,608 & Altitude, top of layer 2 \\
\hline TOP3.DAT & 57,608 & Altitude, top of layer 3 \\
\hline TOP4.DAT & 57,608 & Altitude, top of layer 4 \\
\hline TOP5.DAT & 57,608 & Altitude, top of layer 5 \\
\hline TRAN3.DAT & 103,968 & Transmissivity, layer 3 \\
\hline TRAN4.DAT & 103,968 & Transmissivity, layer 4 \\
\hline TRAN5.DAT & 103,968 & Transmissivity, layer 5 \\
\hline VCONT1.DAT & 105,492 & $\begin{array}{l}\text { Vertical hydraulic } \\
\text { conductivity, layer } 1\end{array}$ \\
\hline VCONT2.DAT & 105,503 & $\begin{array}{l}\text { Vertical hydraulic } \\
\text { conductivity, layer } 2\end{array}$ \\
\hline VCONT3.DAT & 105,503 & $\begin{array}{l}\text { Vertical hydraulic } \\
\text { conductivity, layer } 3\end{array}$ \\
\hline VCONT4.DAT & 105,503 & $\begin{array}{l}\text { Vertical hydraulic } \\
\text { conductivity, layer } 4\end{array}$ \\
\hline WELL83.DAT & 686 & $\begin{array}{l}\text { Well package used to } \\
\text { represent discharge } \\
\text { from pre-1983 wells }\end{array}$ \\
\hline WELL88.DAT & 476 & $\begin{array}{l}\text { Well package used to } \\
\text { represent discharge } \\
\text { from current (1988) } \\
\text { wells }\end{array}$ \\
\hline
\end{tabular}

Table 2.--Model-output files, size, and descriptions

\begin{tabular}{ccc}
\hline File name & $\begin{array}{c}\text { Size } \\
\text { (bytes) }\end{array}$ & \multicolumn{1}{c}{ Description } \\
\hline OUT83.OUT & 431,916 & $\begin{array}{c}\text { Output for steady-state } \\
\text { simulation with pumpage } \\
\text { from pre-1983 production } \\
\text { wells using WELL83.DAT } \\
\text { (table 1) }\end{array}$ \\
\hline OUT88.OUT & 431,851 & $\begin{array}{l}\text { Output for steady-state } \\
\text { simulation with pumpage } \\
\text { from current (1988) } \\
\text { production wells calibrated } \\
\text { to potentiometric heads } \\
\text { during October1988, using } \\
\text { WELL88.DAT (table 1) }\end{array}$ \\
\hline
\end{tabular}

\section{SUMMARY}

This report contains model-input data sets and model-output files for the ground-water-flow model of the Milford-Souhegan glacial-drift aquifer, Milford, New Hampshire (Harte and Mack, in press). The data are presented in American Standard Code for Information Interchange format on three $51 / 4$-inch diskettes that require approximately 2.9 megabytes of storage on an IBM-compatible personal computer.

\section{REFERENCES CITED}

Harbaugh, A.W., 1990a, A simple contouring program for gridded data: U.S. Geological Survey OpenFile Report 90-144, 37 p.

Harbaugh, A.W., 1990b, A computer program for calculating subregional water budgets using results from the U.S. Geological Survey modular threedimensional finite-difference ground-water-flow model: U.S. Geological Survey Open-File Report 90-392, 46 p. 
Harte, P.T., and Mack, T.J., [in press] Geohydrology of, and simulation of ground-water flow in, the Milford-Souhegan glacial-drift aquifer, Milford, New Hampshire: U.S. Geological Survey WaterResources Investigations Report 91-4177.

McDonald, M.G., and Harbaugh, A.W., 1988, A modular three-dimensional finite-difference groundwater-flow model: U.S. Geological Survey Techniques of Water-Resources Investigations, book 6, chap. A1, 586 p.

Pollock, D.W., 1989, Documentation of computer programs to compute and display pathlines using results from the U.S. Geological Survey modular three-dimensional finite-difference groundwater-flow model: U.S. Geological Survey Open File Report 89-381, 188 p. 